\title{
DAMPAK KINERJA KEUANGAN TERHADAP CORPORATE SOCIAL RESPONBILITY PADA SEKTOR PERBANKAN DI INDONESIA
}

\author{
Ella Safitri Laili ${ }^{1)}$, Aminar Sutra Dewi ${ }^{2}$ \\ ${ }^{1,2)}$ Sekolah Tinggi Ilmu Ekonomi KBP \\ Ellasafitrilaili123@gmail.com \\ aminarsutradewi@akbpstie.ac.id
}

\begin{abstract}
This study aims to analyze the effect of firm size and profitability on the corporate social responsibility (CSR) disclosure of the banking companies listed on the Indonesia Stock Exchange (IDX). The population is banking companies which are listed in Indonesia Stock Exchange in 2013-2017 periods. The sample collection technique has been carried out by using purposive sampling method and based on the predetermined criteria, 6 companies have been selected as samples.The data of the financial statement of the companies has been obtained from the official website of IDX. The analytical method used is regression analysis of panel data with the help of application E-Views 8. The initial test is to test the Chow-Test to decide whether the Pooled Least Square or Fixed Effect method is used; and the test Hausman-Test to decide whether the Fixed Effect or Random Effect method can be used.The result of the research shows that the variable profitability has a positive and significant effect on corporate social responbility, firm size has a positive and not significant on corporate social responbility.
\end{abstract}

Keywords: Corporate Social Responbility, Profitability, Firm Size

\section{PENDAHULUAN}

Suatu perusahaan didirikan bukan hanya untuk memperoleh profitability melainkan lebih dari pada itu, yakni sustainability. Perusahaan dituntut bukan hanya bertanggung jawab terhadap para sharehoders, tetapi juga harus memenuhi kewajibannya terhadap pemangku kepentingan (stakeholders). Pengungkapan informasi yang terbuka sangat penting bagi perusahaan publik. Ini dilakukan sebagai wujud kejelasan dalam manajemen perusahaan kepada stakehoders yang membutuhkan. Keterbukaan informasi dari perusahaan digunakan sebagai bahan pertimbangan untuk pengambilan keputusan (Pare et al, 2011).

CSR tidak hanya dilakukan oleh industri pertambangan ataupun industri manufaktur, lembaga keuangan juga turut berperan dalam melaksanakan CSR. Keberadaan perbankan sangat penting bagi perekonomian modern saat ini, bank adalah suatu lembaga keuangan yang bergerak untuk memberikan layanan keuangan yang mengandalkan kepercayaan dari masyarakat untuk mengelola dananya Kasmir 2011. Bank dikatakan sehat apabila bank tersebut dapat menjalankan fungsinya dengan baik. 
Salah satu indikator penilaian tingkat kesehatan bank dapat dilihat dari laporan tahunannya (Morasa, 2011).

Berdasarkan teori slack resources Waddock dan Graves (1997) seperti dikutip dalam Tsoutsoura (2004:18), perusahaan dengan kinerja keuangan yang kuat mempunyai lebih banyak sumber daya yang tersedia untuk berinvestasi dalam ranah kinerja sosial, seperti hubungan karyawan, kepedulian lingkungan, atau hubungan komunitas. Perusahaan dengan tingkat keuangan yang kuat dapat berinvestasi dalam strategi jangka panjang seperti menyediakan jasa untuk komunitas dan karyawannya. Di samping itu, kemungkinan alasan yang mendasari hubungan positif profitabilitas dengan CSR adalah bergantungnya kinerja keuangan pada kinerja CSR perusahaan. Hal ini berarti semakin tinggi tingkat profitabilitas perusahaan maka semakin besar pengungkapan informasi sosial yang dilakukan perusahaan. Dalam hasil penelitian Fahrizqi (2010) menyatakan secara parsial profitabilitas berpengaruh terhadap CSR dengan arah positif ( Wahyuningsih, \& Mahdar, 2018)

Profitabilitas adalah kemampuan perusahaan untuk memperoleh laba dalam hubungan dengan penjualan, total aktiva maupun modal sendiri Sartono, (2010). Rasio profitabilitas memberikan gambaran tentang efektivitas manajemen dalam melaksanakan kegiatan operasionalnya.

Suatu perusahaan yang mempunyai profitabilitas yang tinggi seharusnya melaksanakan tanggung jawab sosial perusahaan secara transparan. Namun pada realitanya bank domestik belum melaksanakanya secara transparan. Deskripsi deskripsi di atas menunjukkan adanya ketidak selerasan sosial antara perusahaan dengan masyarakat. Masyarakat berharap perusahaan perbankan tidak hanya bertanggung jawab kepada investor dan manajemen, tetapi juga pada masyarakat yang lebih luas. (Trisnawati, 2011).

Size merupakan variabel yang banyak digunakan untuk menjelaskan pengungkapan sosial yang dilakukan perusahaan dalam laporan tahunan yang dibuat. Secara umum perusahaan besar akan mengungkapkan informasi lebih banyak daripada perusahaan kecil. Hal ini karena perusahaan besar akan menghadapi resiko politis yang lebih besar dibanding perusahaan kecil. Secara teorits perusahaan besar tidak akan lepas dari tekanan politis, yaitu tekanan untuk melakukan pertanggungjawaban sosial. Pengungkapan sosial yang lebih besar merupakan pengurangan biaya politis bagi perusahaan Hasibuan (2001). Dengan mengungkapkan kepedulian pada lingkungan melalui pelaporan keuangan, maka perusahaan dalam jangka waktu panjang bisa terhindar dari biaya yang sangat besar akibat dari tuntutan masyarakat.

Nadiah, Triwuyono dan Assit (2013) Dalam Pengaruh Kinerja Keungan Terhadap CSR Pada Perusahaan Perbankkan Konvensional Di Indonesia Periode Tahun 2013-2017 menjelaskan bahwa profitabilitas merupakan hasil akhir dari keseluruhan kebijakan dan keputusan yang dipilih oleh manajemen organisasi bisnis. Pada penelitian ini, kemampuan perusahaan menghasilkan laba diukur dengan menggunakan rasio Return On Asset (ROA) (Morasa, 2016). Oleh karena itu, sesuai dengan kajian teori dan data empiris tersebut, dapat dikemukakan bahwa semakin tinggi tingkat profitabilitas maka perusahaan memiliki dana yang cukup untuk dialokasikan kepada kegiatan sosial dan lingkungan sehingga tingkat pengungkapan 
pertanggung jawaban sosial oleh perusahaan akan semakin tinggi. Berdasarkan uraian tersebut, maka hipotesis 1 yang dapat diajukan ialah sebagai berikut:

H1 : Diduga Profitabilitas perusahaan berpengaruh positif dan Signifikan terhadap pengungkapan CSR

Ukuran perusahaan (size) perusahaan merupakan variabel penduga yang banyak digunakan untuk menjelaskan variasi pengungkapan dalam laporan tahunan perusahaan. Hal ini dikaitkan dengan teori agensi, dimana perusahaan besar yang memiliki biaya keagenan yang lebih besar akan mengungkapkan informasi yang lebih luas untuk mengurangi biaya keagenan tersebut. Di samping itu perusahaan besar merupakan emiten yang banyak disoroti, pengungkapan yang lebih besar merupakan pengurangan biaya politis sebagai wujud tanggung jawab sosial perusahaaan (Sembiring, 2015).

Cowen et.al (1987) menyatakan bahwa perusahaan yang lebih besar mungkin akan memiliki pemegang saham yang memperhatikan program sosial yang dibuat perusahaan dalam laporan tahunan, yang merupakan media untuk menyebarkan informasi tentang tanggung jawab sosial keuangan perusahan. Penelitian yang berhasil menunjukkan hubungan kedua variabel ini antara lain adalah penelitian Hasibuan (2001), Gray et al., (2001) dan Sembiring (2003). Akan tetapi tidak semua peneliti mendukung hubungan ukuran perusahaan dengan tanggung jawab sosial perusahaan. Penelitian yang tidak berhasil menunjukkan hubungan kedua variabel ini ditemukan oleh Robert (1992) dan Davey (1982). Berdasarkan penjelasan di atas, maka dapat disimpulkan hipotesis 2 sebagai berikut:

H2 : Diduga size berpengaruh positif dan signifikan terhadap pengungkapan CSR

\section{METODE PENELITIAN}

\section{Data dan Sampel}

Penelitian ini dilakukan pada perusahaan yang terdaftar di Bursa Efek Indonesia. Alasan pemilihan obyek ini adalah dalam pemilihan sampel tidak terdapat kendala kekurangan data, dan titik informasi yang pasti mengenai industri yang telahgo publik.

Dalam penelitian ini Annual Report dan Summary digunakan sebagai sumber data utama. Jenis data yang didapatkan dari Annual Report dan Summary berupa data kuantitatif. Data kuantitatif yang digunakan seperti laporan laba rugi, laporan ekuitas, laporan neraca. Teknik pengumpulan data yang digunakan dalah dokumentasi.

Populasi pada pengamatan ini yaitu Perusahaan perbankan yang terdaftar pada Bursa Efek Indonesia di akhir periode observasi, yaitu 2017 sebanyak 6 Perusahaan .Metode pemilahan sampel pada pengamatan ini dilakukan dengan metode purposive sampling yaitu metode penarikan sampel dengan penilaian yang berdasarkan pada kategori sesuai dengan objek maupun subjek yang untukdiamati. Kriteria untuk pengambilan sampel pada pengamatan ini yaitu :

1. Perusahaan Perbankan Konvesional di Indonesia yang terdaftar di BEI pada periode akhir 2017. 
2. Perusahaan Perbankan Konvesional di Indonesia yang terdaftar di BEI yang mempublikasikan laporan keuangan secara lengkap selama periode penelitian yaitu tahun 2013 - 2017.

3. Perusahaan Perbankan Konvesional di Indonesia yang terdaftar di BEI yang menyediakan data sesuai variabel penelitian.

Berdasarkan kriteria-kriteria tersebut, maka diperoleh sampel pada Tabel berikut:

\section{Tabel 1}

Tabulasi Pengambilan Sampel Menggunakan Purposive Sampling

\begin{tabular}{clc}
\hline No & \multicolumn{1}{c}{ Kiteria } & Jumlah \\
\hline 1 & $\begin{array}{l}\text { Perusahaan perbankan konvensional yang terdaftar di BEI } \\
\text { akhir periode Observasi, yaitu Tahun 2017. }\end{array}$ & 43 \\
& $\begin{array}{l}\text { Perusahaan perbankan konvensional yang tidak terdaftar di } \\
\text { BEI yang mempublikasikan laporan keuangan secaqra } \\
\text { lengkap selama periode Observasi (2013-2017). }\end{array}$ & $(18)$ \\
3 & $\begin{array}{l}\text { Perusahaan perbankan konvensional terdaftar di BEI yang } \\
\text { menyediakan data sesuai variabel penelitian (2013-2017). }\end{array}$ & $(14)$ \\
\hline & \multicolumn{1}{c}{ Jumlah SampelAkhir } & 6 \\
\hline
\end{tabular}

sumber : Diolah Peneliti, 2018

\section{Definisi Operasional Variabel}

Dalam penelitian ini terdiri dari dua macam variabel yaitu variabel independent dan dependent. Variabelindependentyaitu Profitabilitas $\left(\mathrm{X}_{1}\right)$, Ukuran Perusahaan $\left(\mathrm{X}_{2}\right)$. Variabel dependent yaitu Corporate Social Responbility (Y). Selanjutnya dapat diuraikan definisi operasionalnya dari pengamatan ini sebagai berikut:

\section{Tabel 2}

\section{Defenisi Operasional Variabel}

\begin{tabular}{|c|c|c|c|c|c|}
\hline No & Variabel & Defenisi & Pengukuran & Skala & Sumber \\
\hline 1. & $\begin{array}{c}\text { Corporate } \\
\text { Social } \\
\text { Responbility } \\
\text { (Y) }\end{array}$ & $\begin{array}{l}\text { CSR merupakan } \\
\text { sebagai suatu bentuk } \\
\text { pertanggung jawaban } \\
\text { perusahaan terhadap } \\
\text { lingkungan dimana } \\
\text { perusahaan } \\
\text { beroperasi. }\end{array}$ & CSRI $=\frac{\text { Jumlah Item yang diungkapkan }}{79}$ & Rasio & $\begin{array}{c}\text { (Pare, } \\
\text { Sondakh, \& } \\
\text { Morasa, 2011) }\end{array}$ \\
\hline 2. & $\begin{array}{l}\text { Probilitas } \\
\text { (X1) }\end{array}$ & $\begin{array}{l}\text { ROA adalah rasio } \\
\text { yang mengukur } \\
\text { kemampuan } \\
\text { perusahaaan dalam }\end{array}$ & ROA $=\frac{\text { Laba setelah pajak }}{\text { Total Aset }}$ & Rasio & (Ardina, 2016) \\
\hline
\end{tabular}




\begin{tabular}{|c|c|c|c|c|c|}
\hline No & Variabel & Defenisi & Pengukuran & Skala & Sumber \\
\hline & & $\begin{array}{l}\text { menghasilkan laba } \\
\text { dengan seluruh aktiva } \\
\text { yang digunakan. }\end{array}$ & & & \\
\hline 3. & $\begin{array}{l}\text { Size } \\
(\mathrm{X} 2)\end{array}$ & $\begin{array}{l}\text { Size adalah suatu } \\
\text { ukuran yang } \\
\text { menunjukkan besar } \\
\text { kecilnya suatu } \\
\text { perusahaan antara lain } \\
\text { total penjualan, rata- } \\
\text { rata tingkat penjualan, } \\
\text { dan total aktiva. }\end{array}$ & $\begin{array}{c}\text { Size }=\text { Ln }(\text { Total Aktiva }) \\
\text { Keterangan : } \\
\text { Ln: Logaritma Natural }\end{array}$ & Rasio & $\begin{array}{c}\text { Jogiyanto } \\
(2007)\end{array}$ \\
\hline
\end{tabular}

\section{Teknik Analisis Data}

Dalam penelitian ini dilakukan pengujian hipotesis yang bertujuan menguji pengaruh profitabilitas, ukuran perusahaan, terhadap Corporate Social Responbility. Dalam penelitian ini data yang digunakan yaitu data panel, yang merupakan gabungan antara data time series dan cross section. Data sampel sebanyak 6 perusahaan diambil dari data unit cross section dan data time series periode 2013-2017. Analisis statistik deskriptif merupakan metode analisis yang digunakan dalam penelitian ini dan menggunakan Program Eviews(Winarno, 2015) untuk analisi regresi data panel. Persamaan regresi data panel yang digunakan dalam penelitian ini adalah:

\section{$\operatorname{CSR}_{\mathrm{it}}=\alpha+\beta_{1}$ PROFit $+\beta_{2}$ SIZEit $+\mathrm{e} . .$.}

Dimana CSRit merupakan Corporate Social Responbility Perusahaan pada waktu t, $\alpha$ merupakan konstanta (intercept), $\beta 1, \beta 2$ merupakan Koefisien Regresi, PROFit merupakan Profitabilitasitas Perusahaan pada waktu.

Pendekatan yang dilakukan dalam analisis regresi data panel yaitu common effect model (CEM), Fixed effect Model (FEM), random effect model ( REM) (Wulandari, 2017). Ada dua tahapan yang dilakukan untuk menentukan model yang terbaik digunakan antara model tersebut yaitu: Uji Chow, untuk menentukan model mana yang terbaik antara common effect model (CEM) dengan Fixed effect Model (FEM). Uji Hausman, dilakukan untuk menentukan model mana yang terbaik digunakan antara Fixed effect Model (FEM) dengan random effect model ( REM). Model regresi yang baik harus menghasilkan estimasi linear tidak bias (BestLinear Unbiased Estimator).

Yusra \& Hadya (2017) mendeskripsikan, Kriteria pengujian menggunakan taraf signifikansi sebesar 0.05. Apabila nilai signifikasi $<5 \%$ maka $\mathrm{H} 0$ ditolak atau Ha diterima dan apabila nilai signifikasi $\geq 5 \%$ maka $\mathrm{H} 0$ diterima atau Ha ditolak. Yusra \& Hadya (2017). 


\section{HASIL DAN PEMBAHASAN}

\section{Uji Statistik Deskriptif Variabel}

Uji statistik deskriptif bertujuan untuk memberikan gambaran umum obyek penelitian. Perhitungan statistik deskriptif dalam penelitian ini meliputi nilai minimum, maksimum, rata-rata, maupun standar deviasi dari masing-masing variabel. Variabel dependen pada penelitian ini adalah corporate social responbility sedangkan variabel independen penelitian ini adalah profitabilitasdansize . Distribusi statistik untuk masing-masing variabel dalam penelitian ini terdapat pada Tabel 2 dibawah ini:

Tabel 3

Hasil Uji Statistik Deskriptif

\begin{tabular}{lcccc}
\hline \multicolumn{1}{c}{ Variabel } & Minimum & Maksimum & Mean & $\begin{array}{c}\text { Standar } \\
\text { Deviasi }\end{array}$ \\
\hline CSR & 16.46000 & 41.77000 & 34.85267 & 4.442687 \\
$\begin{array}{l}\text { Profitabilitas } \\
\text { (ROA) }\end{array}$ & 0.600000 & 2.600000 & 1.394000 & 0.687798 \\
$\begin{array}{l}\text { Ukuran Perusahaan } \\
\text { (SIZE) }\end{array}$ & 12.87000 & 18.55000 & 15.89533 & 1.587424 \\
Sumber $:$ datadiolah, Eviews 8 & & & \\
\hline
\end{tabular}

Pada tabel 3 menunjukkan angka-angka deskriptif dari masing-masing variabel dengan jumlah observasi sebanyak 30 (tiga puluh). Penjelasan dari analisis deskriptif adalah sebagai berikut :

Corporate Social Responbility yang merupakan variabel terikat dengan menggunakan CSDI sebagai alat ukur dapat dilihat nilai minimum sebesar 16,46 yang diperoleh Bank Capital Indonesia Tbk pada tahun 2017 dan nilai maximum sebesar 41,77 yang diperoleh Bank Rankyat Indonesia Agroniaga Tbk pada tahun 2017. Sedangkan nilai rata-rata (mean) secara keseluruhan sebesar 34,85. Nilai rata-rata CSDI diatas 1 artinya harga pasar saham lebih besar dari pada nilai bukunya dan nilai perusahaan dikatakan baik. Dengan nilai median sebesar 34,81 dan standar deviasi sebesar 4,44 yang menunjukkan penyebaran data yang lebih kecil karena nilainya lebih rendah dari nilai rata-rata (mean).

Profitabilitas merupakan variabel bebas dengan menggunakan ROA sebagai alat ukurnya dan dapat dilihat nilai maximum sebesar 2,60 yang dapat diartikan perusahaan mampu menghasilkan profit hingga 2,60 \% dari total modal yang dimiliki oleh perusahaan yang diperoleh Bank Negara Indonesia (Persero) Tbk pada tahun 2014 dan nilai minimum sebesar 0,60 diperoleh Bank Sinarmas Tbk pada tahun 2017. Sedangkan nilai rata-rata (mean) secara keseluruhan sebesar 1,39. Artinya, laba bersih 1,39 kali dari modal sendiri dengan nilai median sebesar 1,06 dan standar deviasi sebesar 0,68 yang menunjukkan penyebaran data yang lebih besar karena nilainya lebih tinggi dari nilai rata-rata (mean).

Ukuran Perusahaaan merupakan variabel bebas yang menggunakan Ln sebagai alat ukurnya. Nilai minimum diperoleh Bank Negara Indonesia (Persero) Tbk sebesar 12,87 pada tahun 2013 dan nilai maximum diperoleh Bank Rankyat Indonesia 
Agroniaga Tbk sebesar 18,55 pada tahun 2016. Nilai rata-rata (mean) secara keseluruhan sebesar 15,89. Artinya, total hutang 15,89 kali dari total modal dengan nilai median sebesar 15,99 dan standar deviasi sebesar 1,58 yang menunjukkan penyebaran data lebih kecil karena nilainya lebih rendah dari nilai rata-rata (mean).

\section{Pemilihan Regresi Data Panel}

Dalam data panel untuk pemilihan model yang terbaik dilakukan tahap analisis dengan cara melakukan estimasi model Common Effect (CEM), Fixed Effect (FEM), dan Random Effect (REM). Persamaan regresi profitabilitas dengan menggunakan proksi return on asset adalah sebagai berikut:

$$
\log C \text { SRit }=\alpha+\beta 1 \text { LogPROFit }+\beta 2 \text { SIZEit+eit }
$$

Persamaan ini menggunakan transformasi logaritma dalam menentukan model yang terbaik. Hasil statistik yang diperoleh dalam pengestimasian model CEM, FEM, dan REM adalah sebagai berikut:

Tabel 4

Tabel Estimasi CEM, FEM, dan REM

\begin{tabular}{ccccccrc}
\hline \multirow{2}{*}{ Variabel } & \multicolumn{2}{c}{ Common Effect } & \multicolumn{2}{c}{ Fixed Effect } & \multicolumn{2}{c}{ Random Effect } \\
\cline { 2 - 7 } & t-statistik & prob & t-statistik & prob & t-statistik & prob \\
\hline & - & & - & & - & \\
PROF (ROA) & 1.042229 & 0.3065 & 2.132927 & 0.0443 & 2.099555 & 0.0453 \\
SIZE(LN) & 1.332569 & 0.1938 & 1.623700 & 0.1187 & 1.796655 & 0.0836
\end{tabular}

Sumber : data diolah, Eviews 8

Persamaan regresi profitabilitas dengan menggunakan return on asset adalah sebagai berikut:

$$
\operatorname{LogCSR}_{\mathrm{it}}=\alpha+\beta 1 \operatorname{LogPROF} 1 \mathrm{it}+\beta_{2} \mathrm{SIZE}_{2 \mathrm{it}}+\text { eit }
$$

Persamaan ini menggunakan transformasi logaritma dalam menentukan model yang terbaik. Hasil statistik yang diperoleh dalam pengestimasian model CEM, FEM, dan REM adalah sebagai berikut: 


\section{Tabel 5}

Hasil Uji Normalitas

\begin{tabular}{cc}
\hline Jarque-Bera & Probability \\
\hline 0.772685 & 0.679538 \\
\hline
\end{tabular}

Sumber :data diolah, Eviews 8

Berdasarkan tabel 5 diatas, hasil estimasi likuiditas yang menggunakan indikator current rasio terhadap leverage didapatkan. Nilai probability lebih besar dari alpha (0.679>0.05) maka dapat dikatakan bahwa residual dalam model penelitian ini telah berdistribusi normal.

Tabel 6

Uji Chow

\begin{tabular}{lrrr}
\hline Effects Test & Statistic & d.f. & Prob. \\
\hline \hline Cross-section F & 5.901673 & $(5,22)$ & 0.0013 \\
Cross-section Chi-square & 25.521053 & 5 & 0.0001 \\
\hline
\end{tabular}

Sumber : data diolah, Eviews 8

Tabel 7

Uji Hausman

\begin{tabular}{llrc}
\hline Test Summary & \multicolumn{1}{c}{ Chi-Sq. } \\
Statistic Chi-Sq. d.f. & Prob. \\
\hline \hline Cross-section random & 5.901299 & 2 & 0.0523 \\
\hline
\end{tabular}

Sumber : data diolah, Eviews 8

Uji Hausman Untuk Profitabilitas yang menggunakan proksi Return On Asset.

\section{Analisis Regresi Data Panel}

Dalam penelitian ini teknik analisis data digunakan untuk mengolah, membahas sampel yang sudah diperoleh dan untuk menilai hipotesis yang diduga. Hasil pengujian penelitian dengan profitabilitas menggunakan indikator Return On Asset dapat dilihat pada Tabel berikut:

Tabel 8

Tabel Hasil Estimasi Regresi Data Panel

\begin{tabular}{ccrrr}
\hline Variable & Coefficient & Std. Error & \multicolumn{1}{c}{ t-Statistic } & \multicolumn{1}{c}{ Prob. } \\
\hline C & 18.88597 & 12.66239 & 1.491501 & 0.1474 \\
ROA & -3.280874 & 1.562652 & -2.099555 & 0.0453 \\
LN & 1.292218 & 0.719236 & 1.796655 & 0.0836
\end{tabular}

Sumber: data diolah, Eviews 8 
Persamaan Regresi Data Panel Random Effect Model adalah sebagai berikut:

$$
\mathrm{CSR}_{\mathrm{it}}=18.885-3.2808 \mathrm{PROF}_{\mathrm{it}}+1.2922 \mathrm{SIZE}_{\mathrm{it}}
$$

Angka pada Persamaan Regresi Data Panel didapatkan dari nilai coefficient variabel. Nilai konstanta sebesar 18.885 ini menjelaskan jika diasumsikan nilai variabel independen bernilai 0 (tidak ada), maka nilai Leverage bernilai tetap sebesar 18.885. Koefisien Profitabilitas (return on asset) sebesar -3.2808 artinya setiap peningkatan variabel likuiditas sebanyak 1 satuan berarti akan menurunkan variabel $\operatorname{csr}$ sebanyak -3.2808 serta beranggapan variabel lain dalam bentuk konstan. Koefisien ukuran perusahaan sebesar 1.2922 artinya setiap peningkatan variabel ukuran perusahaan sebanyak 1 satuan berarti akan menurunkan variabelcsr sebanyak 1.2922 serta beranggapan variabel lain dalam bentuk konstan.

\section{Hasil Pengujian Hipotesis}

Uji hipotesis bertujuan untuk mengetahui seberapa besar pengaruh suatu variabel bebas terhadap variabel terikat. Kriteria pengujian berupa jika nilai probability Thitung $>$ Ttabel maka $\mathrm{H}_{0}$ ditolak dan Ha diterima dan jika nilai probability $\mathrm{T}_{\text {hitung }}<\mathrm{T}_{\text {tabel }}$ maka Ha ditolak dan $\mathrm{H}_{0}$ diterima. Dengan tingkat signifikan sebesar 0,05 (5\%).

Pada tabel 8 untuk variabel Profitabiitas menunjukkan nilai Thitung < Ttabel $2.099555<2.048407$ atau probability $0.0453<0.05$ maka $\mathrm{H}_{0}$ ditolak dan Ha diterima. Untuk variabel Ukuran Perusahaan menunjukkan nilai Thitung < Ttabel $1.796655<$ 2.048407 atau probability $0.0836>0.05$ maka $\mathrm{H}_{0}$ diterima dan $\mathrm{H}_{\mathrm{a}}$ ditolak.

\section{PEMBAHASAN}

\section{Pengaruh Profitabilitas Terhadap Corporate Social Responbility}

Dari hasil estimasi dengan menggunakan program eviews 8 dapat disimpulkan bahwa profitabilitas sebagai hipotesis $1\left(\mathrm{H}_{1}\right)$ yang menyatakan profitabilitas terhadap Corporate Social Responbility ini berpengaruh secara signifikan. Dengan demikian maka disimpulkan bahwa hipotesis pertama diterima. Hal ini menunjukkan bahwa profitabilitas dapat mempengaruhi Corporate Social Responbility perusahaan. Oleh karena itu, dapat dikemukakan bahwa semakin tinggi tingkat profitabilitas maka perusahaan memiliki dana yang cukup untuk dialokasikan kepada kegiatan sosial dan lingkungan sehingga tingkat pengungkapan pertanggung jawaban sosial oleh perusahaan akan semakin tinggi.

Dalam penelitian Tsoutsoura (2004:18) yang menemukan pengaruh positif antara profitabilitas terhadap CSR. Berdasarkan teori slack resources Waddock dan Graves (1997) seperti dikutip dalam Tsoutsoura (2004:18), perusahaan dengan kinerja keuangan yang kuat mempunyai lebih banyak sumber daya yang tersedia untuk berinvestasi dalam ranah kinerja sosial, seperti hubungan karyawan, kepedulian lingkungan, atau hubungan komunitas. Perusahaan dengan tingkat keuangan yang kuat dapat berinvestasi dalam strategi jangka panjang seperti menyediakan jasa untuk komunitas dan karyawannya. Di samping itu, kemungkinan alasan yang mendasari hubungan positif profitabilitas dengan CSR adalah bergantungnya kinerja keuangan 
pada kinerja CSR perusahaan. Hal ini berarti semakin tinggi tingkat profitabilitas perusahaan maka semakin besar pengungkapan informasi sosial yang dilakukan perusahaan. Dalam hasil penelitian Fahrizqi (2010) menyatakan secara parsial profitabilitas berpengaruh terhadap CSR dengan arah positif ( Wahyuningsih, \& Mahdar, 2018).

Bila pengungkapan Corporate Social Responsibility meningkat maka tingkat pengembalian aset akan meningkat begitu juga sebaliknya, ketika pengungkapan Corporate Social Responsibility turun, maka tingkat pengembalian aset juga akan menurun. Hasil penelitian ini sejalan dengan penelitian yang dilakukan oleh Nistantya (2010) yang menyatakan bahwa pengungkapan Corporate Social Responsibility berpengaruh positif dan signifikan terhadap ROA ( Wahyuningsih, \& Mahdar, 2018)..

\section{Pengaruh Ukuran Perusahaan Terhadap Corporate Social Responbility}

Berdasarkan Hipotesis 2 dalam penelitian ini yaitu bahwa diduga ukuran perusahaan berpengaruh positif dan signifikan terhadap CSR diterima. Pada penelitian ini diperoleh hasil bahwa ukuran perusahaan secara statistik berpengaruh positif dan signifikan terhadap luas pengungkapan tanggung jawab sosial perusahaan (CSR). Adanya hubungan signifikan antara variabel ukuran perusahaandan pengungkapan sosial mengandung arti bahwa semakin besar suatu perusahaan, maka akan cenderung melakukan pengungkapan CSR yang lebih luas. Perusahaan besar merupakan emiten yang banyak disorot, pengungkapan yang lebih besar merupakan pengurangan biaya politis sebagai wujud tanggung jawab sosial perusahaan (Purnasisi \& Sudarno 2018).

Secara teoritis perusahaan besar tidak akan lepas dari tekanan, dan perusahaan yang lebih besar dengan aktivitas operasi dan pengaruh yang lebih besar terhadap masyarakat mungkin akan memiliki pemegang saham yang memperhatikan program sosial yang dibuat perusahaan, sehingga pengungkapan tanggung jawab sosial perusahaan akan semakin luas. Dari sisi tenaga kerja, dengan semakin banyaknya jumlah tenaga kerja dalam suatu perusahaan, maka tekanan pada pihak manajemen untuk memperhatikan kepentingan tenaga kerja akan semakin besar. Program berkaitan dengan tenaga kerja yang merupakan bagian dari tanggung jawab sosial perusahaan, akan semakin banyak dilakukan oleh perusahaan (Pada, n.d.).

Hal ini berarti program tanggung jawab sosial perusahaan juga semakin banyak dan akan diungkapkan dalam laporan tahunan. Hasil penelitian ini mendukung hasil penelitian sebelumnya yang berkaitan dengan pengaruh ukuran perusahaan terhadap pengungkapan tanggung jawab sosial. Penelitian yang mendukung tersebut adalah penelitian yang dilakukan oleh Hasibuan (2001), Gray et al., (2001) dan Sembiring (2003) (Purnasisi \& Sudarno 2018).

\section{SIMPULAN}

Hasil dari penelitian tentang pengaruh profitabilitas (ROA), ukuran perusahaan (SIZE) terhadap Corporate Social Responbility dapat disimpulkan bahwa pertama, Profitabilitas berpengaruh signifikan terhadap Corporate social Responbility pada perusahaan yang terdaftar di Bursa Efek Indonesia periode 2013-2017. Artinya, 
semakin tinggi tingkat profitabilitas maka perusahaan memiliki dana yang cukup untuk dialokasikan kepada kegiatan sosial dan lingkungan sehingga tingkat pengungkapan pertanggung jawaban sosial oleh perusahaan akan semakin tinggi. Kedua, ukuran perusahaan (SIZE) berpengaruh signifikan terhadap Corporate Social Responbility pada perusahaan yang terdaftar di Bursa Efek Indonesia periode 2013-2017. Artinya, ukuran perusahaandan pengungkapan sosial mengandung arti bahwa semakin besar suatu perusahaan, maka akan cenderung melakukan pengungkapan CSR yang lebih luas.

\section{UCAPAN TERIMA KASIH}

Selesainya penulisan ini, karena penulis banyak menerimamasukan dan dorongan baik motivasi secara moral atau spiritual. Oleh karena itu penulis ingin mengucapkan terimakasih kepada: Bapak Febryandhie Ananda, SE, M.Si. selaku ketua STIE"KBP" Padang. Ibu Febsri Susanti, SEI, MM. selaku ketua Program Studi Manajemen. Ibu Aminar Sutra Dewi SE.MSi sebagai dosen pembimbing dalam pembuatan artikel ini dan penulis banyak berterima kasih atas kesabaran, kepedulian dan kesempatan yang sudah diberikan, penulis berharap kebaikan bapak bisa dibalas oleh Tuhan Yang Maha Esa. Seluruh bagianyang sudah banyak menolong penulis yang tidak dapat penulis sampaikan satu persatu.

\section{DAFTAR PUSTAKA}

Andriza, R., \& Yusra, I. (2019). Pengaruh kepemilikan manajerial dan kebijakan deviden terhadap kemakmuran Investor dan nilai perusahaan yang tercatat pada indeks LQ45. INA-Rxiv.

Angraini, I., \& Yusra, I. (2019). Pendekatan data panel terhadap return saham: studi empiris pada perusahaan LQ45. INA-Rxiv.

Arbi Tovani - Pengaruh Kinerja Keuangan Terhadap Corporate Social Responsibility Pada Perusahaan Perbankan Konvensional Di Indonesia Periode Tahun 2009 2013.

Ardimas, W., Ekonomi, F., \& Gunadarma, U. (2014). Pengaruh Kinerja Keuangan Dan Corporate Social Responsibility Terhadap Nilai Perusahaan Pada Bank, 18, 5766.

Danil, A., \& Yusra, I. (2019). Pengaruh kausal antara ukuran perusahaan, nilai buku dan likuiditas saham di Bursa Efek Indonesia. INA-Rxiv.

Erawati, L., \& Dewi, A. S. (2019). Peran Profitabilitas Sebagai Variabel Interverning Dan Pengaruh Struktur Modal Terhadap Nilai Perusahaan. INA-Rxiv.

Fajri, I., \& Dewi, A. S. (2019). Analisis Likuiditas, Profitabilitas, dan Return Saham pada Perusahaan Manufaktur di Indonesia. INA-Rxiv. 
Hadya, R. (2014a). Analisis likuiditas, solvabilitas, nilai pasar dan return saham: studi empiris pada perusahaan sektor perbankan yang terdaftar di Bursa Efek Indonesia. Jurnal Riset Manajemen Dan Akuntansi, 3(1), 107-118.

Hadya, R. (2014b). Earning Surprise, Ketepatan Waktu Pengumuman Laporan Keuangan Dan Reaksi Pasar. Jurnal Riset Manajemen Dan Akuntansi, 1(2).

Hadya, R., Begawati, N., \& Yusra, I. (2017). Analisis Efektivitas Pengendalian Biaya, Perputaran Modal Kerja, dan Rentabilitas Ekonomi Menggunakan Regresi Data Panel. Jurnal Pundi, 01(03), 1-35.

Hanafi, D., \& Yusra, I. (2019). Tangibility, liquidity, growth opportunity, dan leverage: studi pada perusahaan terdaftar di Bursa Efek Indonesia. INA-Rxiv, (2001).

Handayani, F., \& Martha, L. (2019). Hubungan Antara Profitabilitas Dengan Nilai Perusahaan Yang Dimoderasi Oleh Corporate Social Responsibility. INA-Rxiv.

Harahap, R. L., \& Sari, L. F. (2019). Analisis Nilai Perusahaan Berdasakan Profitabilitas, Ukuran Perusahaan, Dan Struktur Modal Di Indonesia. INA-Rxiv.

Kartin, Y. R., \& Dewi, A. S. (2019). Karakteristik Dewan Komisaris Dan Dampaknya Terhadap Kinerja Keuangan. INA-Rxiv.

Kurniawan, A., \& Yusra, I. (2019). Apakah profitabilitas dan nilai buku berdampak terhadap return saham?: studi empiris pada perusahaan LQ45. INA-Rxiv.

Maritim, U., \& Ali, R. (2013). Analisis Pengaruh Kinerja Keuangan Terhadap Corporate Social Responsibility Pada Perusahaan Perbankan Yang Terdaftar Di Bursa Efek Indonesia, 4(2), 31-40.

Martha, L. (2018). Peranan Analisis Laporan Keuangan terhadap Pengambilan Keputusan Pemberian Kredit Pada PT. BPR LPN Sungai Rumbai Kabupaten Dharmasraya. INA-Rxiv.

Martha, L., Sogiroh, N. U., Magdalena, M., \& Susanti, F. (2018). Profitabilitas dan Kebijakan Dividen terhadap Nilai Perusahaan. Jurnal Benefita, 3(2), 227-238.

Mulfita, A., \& Yusra, I. (2019). Analisis regresi data panel terhadap likuiditas saham di Indonesia. INA-Rxiv.

Monica, S., \& Dewi, A. S. (2019). Pengaruh Kepemilikan Institusional dan Dewan Komisaris Independen Terhadap Kinerja Keuangan di Bursa Efek Indonesia. INA-Rxiv.

Pare, Y. K., Sondakh, J. J., \& Morasa, J. (2011). Pengaruh Karakteristik Perusahaan Terhadap Pengungkapan Corporate Social Responsibility Pada Perusahaan 
Perbankan Konvensional Di Indonesia, 317-329.

Purnama, S., \& Mayliza, R. (2019). Nilai Perusahaan Di Lihat Dari Aspek Profitabilitas, Ukuran Perusahaan Dengan Struktur Modal Sebagai Variabel Intervening. INA-Rxiv.

Purnasisi \& Sudarno (2018). Analisis Pengaruh Size, Profitabilitas Dan Leverage Terhadap Pengungkapan Csr Pada Perusahaan Yang Terdaftar Di Bursa Efek Indonesia.

Putra, A. D., \& Yusra, I. (2019). Peran profitabilitas dalam memoderasi pengaruh free cash flow terhadap kebijakan dividen di Indonesia. INA-Rxiv.

Putra, I., \& Yusra, I. (2019). Analisis likuiditas saham menggunakan regresi data panel. INA-Rxiv.

Qusibah, V. L., \& Yusra, I. (2019). Profitabilitas, dan Ukuran Perusahaan Sebagai Faktor Penentu Leverage Perusahaan Di Indonesia. Jurnal Pundi, 03(01), 1326. https://doi.org/10.31575/jp.v3i1.125

Ramadhani, F. N. (2017). Analisis Pengaruh Kinerja Keuangan Terhadap Tanggung Jawab Fidanuzulacantik@Gmail.Com, 6.

Saputra, J., \& Martha, L. (2019). Analisis Kinerja Keuangan Dan Nilai Perusahaan, Serta Pengaruhnya Terhadap Harga Saham. INA-Rxiv.

Sondakh \& Morasa (2016). Pengaruh Karakteristik Perusahaan Terhadap Pengungkapan Corporate Social Responsibility Pada Perusahaan Perbankan Konvensional Di Indonesia.

Suciwati, Pradnyan \& Ardina (2016). Pengaruh Corporate Social Responsibility Terhadap Kinerja Keuangan (Pada Perusahaan Sektor Pertambangan Di Bei Tahun 2010-2013). Jurnal Bisnis Dan Kewirausahaan Vol.12. No.2 Juli 2016

Suhartono, \& Yusra, I. (2019). Analisis perbandingan kinerja keuangan bank konvensional dengan bank syariah yang terdaftar di BEI. INA-Rxiv, 1-9.

Wahyudi, R., \& Martha, L. (2019). Analisis Modal Intelektual Dan Kinerja Keuangan Dan Pengaruhnya Terhadap Nilai Perusahaan. INA-Rxiv.

Wahyuni, I., \& Mayliza, R. (2019). Peran Kebijakan Deviden Dalam Memediasi Pengaruh Profitabilitas Terhadap Nilai Perusahaan. INA-Rxiv.

Wahyuningsih, A., \& Mahdar, N. M. (2018). Pengaruh Size , Leverage Dan

Profitabilitas Terhadap Pengungkapan Csr Pada Perusahaan Manufaktur Yang 
Terdaftar Di Bursa Efek Indonesia, (February).

Winarno, Wing Wahyu. (2015). Analisis Ekonometrika Dan Statistika Dengan Eviews (4th Ed.). Yogyakarta: Upp Stim Ykpn.

Wulandari, N. (2017). Analisis Faktor-Faktor Yang Mempengaruhi Inflasi Pada Kota Metropolitan Di Indonesia Dengan Menggunakan Analisis Data Panel, 3(2), $34-42$.

Yusra, I., Hadya, R., \& Egawati, N. (2017). Analisis Efektivitas Pengendalian Biaya, Perputaran Modal Kerja, Dan Rentabilitas Ekonomi Menggunakan Regresi Data Panel. Jurnal Pundi, Vol. 01, No. 03, November 2017 Analisis, 1(3), 153166.

Yusra, I., Hadya, R., Begawati, N., \& Istiqomah, L. (2019). Panel data model estimation: the effect of managerial ownership, capital structure, and company size on corporate value Panel data model estimation : the effect of managerial ownership, capital structure, and company size on corporate value. Journal of Physics: Conference Series, 1175, 1-6. https://doi.org/10.1088/1742$6596 / 1175 / 1 / 012285$

Yusra, I., Hadya, R., \& Fatmasari, R. (2019). The Effect of Retained Earnings on Dividend Policy from the Perspective of Life Cycle. Advances in Social Science, Education and Humanities Research, 203(Iclick 2018), 216-220.

Yusuf, D., \& Yusra, I. (2019). Faktor-faktor yang mempengaruhi struktur modal perusahaan. INA-Rxiv. 